\title{
Pengembangan Multimedia Interaktif Subener (Sumber Energi) Pada Materi Sumber Energi Kelas IV SD
}

\author{
Dita Ayu wardyaning Siwi ${ }^{1}$ Sutrisno Sahari ${ }^{2}$ Ilmawati Fahmi Imron ${ }^{3}$ \\ ${ }^{1}$ Program Studi PGSD, Universitas Nusantara PGRI Kediri \\ Email: ditaayuwardyaningsiwi@gmail.com \\ ${ }^{2}$ Program Studi PGSD, Universitas Nusantara PGRI Kediri \\ Email: sutrisnosahari@gmail.com \\ ${ }^{3}$ Program Studi PGSD, Universitas Nusantara PGRI Kediri \\ Email: ilmawati@unpkediri.ac.id
}

\begin{abstract}
After conducting research through observations on science learning in grade $I V$, the results obtained by teachers when learning energy source material did not use the media only using the lecture method, so research was carried out on the development of subenerary media. The purpose of this study is to determine the validity, effectiveness and practicality of the subener media. This study uses the ADDIE questionnaire and test instrument model. For data analysis using quantitative and qualitative techniques with the subject of 22 students of SDN Lirboyo 2. This study obtained $92 \%$ media validity results and $90 \%$ validity material was declared very valid, $80 \%$ percentage of classical learning completeness was declared effective, student questionnaires received $92 \%$ responses and questionnaires teachers get a response 90\% stated practical. Research on the development of the Locked media subgenerator can be used for energy source materials in the fourth grade of elementary school.
\end{abstract}

Keywords : Energy Sources; Multimedia, Learning Media

\begin{abstract}
Abstrak. Setelah melakukan penelitian melalui observasi pada pembelajaran IPA di kelas IV, didapat hasil guru saat pembelajaran materi sumber energi tidak menggunakan media hanya menggunakan metode ceramah, maka dilakukan penelitian pengembangan media subener. Tujuan pada penelitian ini yaitu untuk mengetahui kevalidan, keefektifan dan kepraktisan pada media subener. Penelitian ini menggunakan model ADDIE instrumen angket dan tes. Untuk analisis data menggunakan teknik kuantitatif dan kualitatif dengan subjek 22 siswa SDN Lirboyo 2. Penelitian ini diperoleh hasil kevalidan media 92\% dan kevalidan materi 90\% dinyatakan sangat valid, $80 \%$ presentase ketuntasan belajar klasikal dinyatakan efektif, angket siswa mendapat respon 92\% dan angket guru mendapat respon 90\% dinyatakan praktis. Penelitian pada pengembangan media subener disimpulkan dapat digunakan pada materi sumber energi pada kelas IV Sekolah Dasar.
\end{abstract}

Kata Kunci : Sumber Energi, Multimedia; Media Pembelajaran

\section{PENDAHULUAN}

Perkembangan tekonologi pada zaman sekarang semakin berkembang dan berpengaruh bagi semua kalangan, bahkan sudah sampai pada bidang pendidikan. Dengan adanya teknologi diharapkan mampu membantu siswa menjadi semangat, tertarik dan senang selama kegiatan pembelajaran berlangsung kemudian siswa dapat memperoleh hasil belajar yang maksimal.

Pembelajaran di kelas IV SDN 2 Lirboyo Kota Kediri pada kegiatan pembelajaran terlihat guru ketika mengajar cenderung hanya menggunakan metode ceramah dan tanya jawab. Guru hanya menggunakan buku pegangan guru dan sebagai bahan ketika mengajar. Untuk itu, perlu adanya 
media pembelajaran. Dengan adanya media pembelajaran diharapkan agar proses pembelajaran di kelas berjalan secara efektif serta meningkatkan minat belajar peserta didik.

Media memiliki fungsi yang sangat penting pada kegiatan pembelajaran. Menurut Sukiman (2012:44), "Media pembelajaran memiliki fungsi yang sangat penting yaitu dapat memperjelas penyajian pesan dan informasi sehingga dapat memperlancar dan meningkatkan proses hasil belajar". Dengan adanya media dapat mempermudah siswa dalam memahami materi yang diajarkan. Media pembelajaran yang dikembangkan peneliti berupa multimedia interaktif subener. Media pembelajaran ini digunakan pada materi sumber energi. Menurut Suranto (2015:18), "Media pembelajaran merupakan suatu sarana yang digunakan untuk menyampaikan pesan dari seorang komunikator kepada komunikan "Media merupakan alat yang digunakan sebagai perantara dalam menyampaikan suatu pesan. Dengan adanya media pembelajaran ini, siswa dapat mempelajari materi sumber energi.

Menurut Daryanto (2015:69), "Multimedia interaktif adalah suatu program pembelajaran yang berisi kombinasi teks, gambar, grafik, suara, video, animasi, simulasi secara terpadu dan sinergis dengan bantuan perangkat computer atau selanjutnya untuk mencapai tujuan pembelajaran tertentu dimana pengguna dapat secara aktif berinteraksi dengan program. "Multimedia interaktif subener termasuk media pembelajaran bentuk digital karena didalam media berisi teks, gambar, suara, video dan animasi. Menurut Munadi (2010:152-153) multimedia interaktif memiliki kelebihan dan kekurangan. Kelebihan pada media interaktif subener adalah: (1) informasi dan pesan dalam media mudah dimengerti; (2) meningkatkan motivasi belajar; (3) memberikan umpan balik. Sedangkan kelemahan multimedia interaktif subener adalah: (1) pengembangan memerlukan adanya tim yang profesional; (2) pengembangan memerlukan waktu yang cukup lama.

Berdasarkan penjelasan diatas, tujuan melakukan penelitian ini adalah untuk (1) mengetahui kevalidan media interaktif subener pada kelas IV; (2) untuk mengetahui keefektifan media interaktif subener di kelas IV; (3) untuk mengetahui kepraktisan media interaktif subener di kelas IV.

\section{METODE PENELITIAN}

Jenis penelitian ini adalah penelitian pengembangan yang bertujuan untuk mengetahui kevalidan, keefektifan dan kepraktisan media interaktif subener pada materi sumber energi kelas IV SDN Lirboyo 2 Kota Kediri. Pada penelitian pengembangan media ini, menggunakan model pengembangan ADDIE . Adapun langkah dalam model ADDIE dapat digambarkan sebagai berikut :

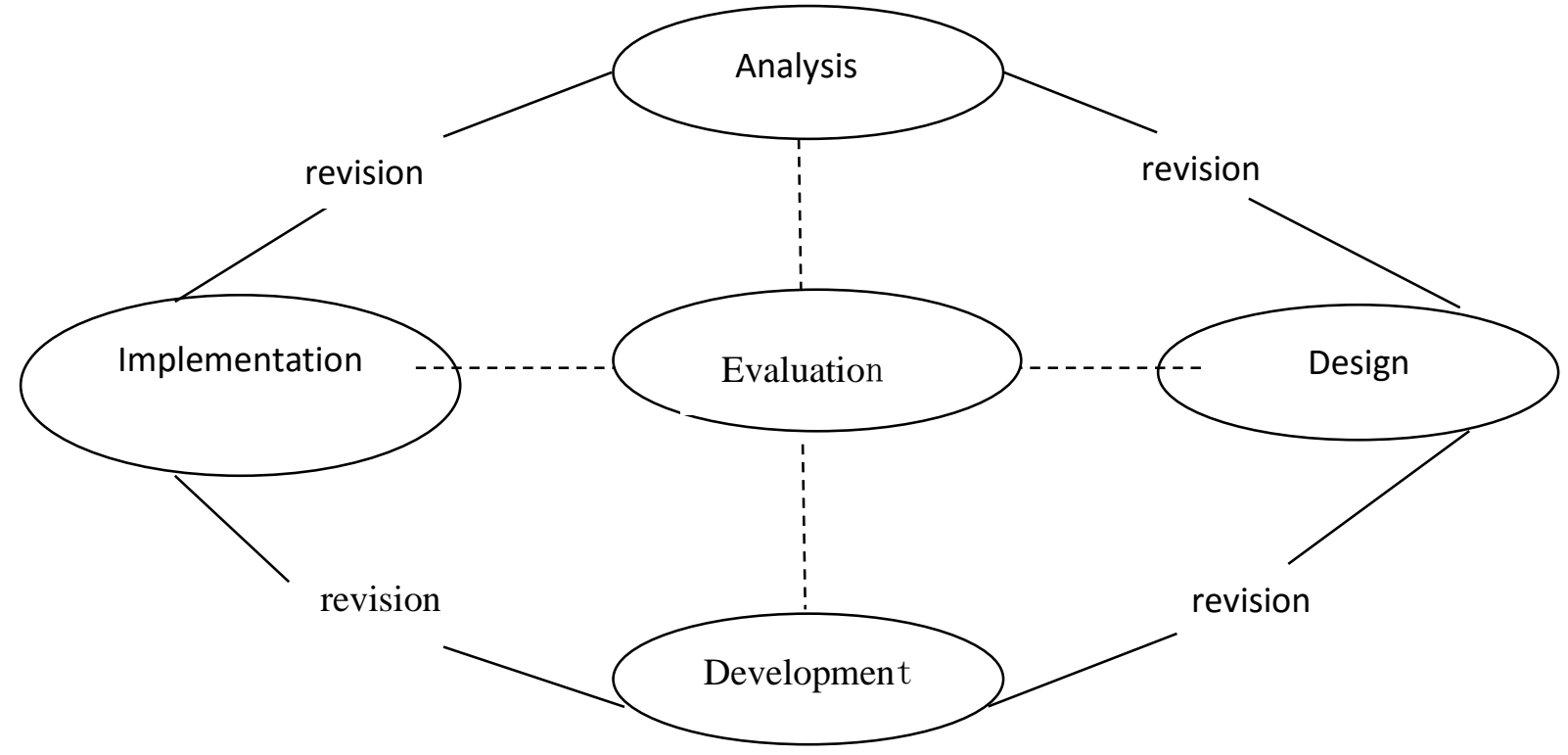


Menurut Tegeh, Jampel dan Pudjawan (2014:41), “Model penelitian ADDIE merupakan suatu desain sistem pembelajaran yang sistematik". Subjek pada penelitian ini adalah siswa kelas IV SDN Lirboyo 2 Kota Kediri, dengan melibatkan satu orang guru kelas IV di SDN tersebut sebagai sumber informasi penelitian. Subjek penelitian dipilih berdasarkan permasalahan bahwa hasil belajar siswa pada materi sumber energi masih kurang dari KKM. Pada tahap pengumpulan data penelitian dilakukan dengan teknik wawancara dengan guru kelas IV SDN Lirboyo 2 Kota Kediri, angket validasi media, angket validasi materi dan angket respon guru. Berikut tahapan-tahapan analisis data yang dilakukan sebagai berikut.

\section{A. Analisis Data Angket}

Analisis ini mengenai analisis data validasi dan analisis data kepraktisan.

1. Angket dianalisis secara kuantitatif dengan menghitung perolehan skor maksimal yang diperoleh dengan kriteria pilihan jawaban lembar validasi menurut Sugiyono (2019:147) sebagai berikut.

Tabel 1. Pilihan Jawaban Untuk Angket Vaidasi

\begin{tabular}{|c|c|}
\hline Jawaban & Skor \\
\hline Sangat Baik & 5 \\
\hline Cukup & 4 \\
\hline Kurang Baik & 3 \\
\hline Tidak Baik & 2 \\
\hline Sangat Tidak Baik & 1 \\
\hline
\end{tabular}

2. Menghitung presentase nilai dari perolehan angket validasi media, validasi materi dan angket guru. Menurut Riduwan (2015:15) rumus yang digunakan untuk menghitung presentase adalah sebagai berikut.

$$
\text { Presentase }=\frac{\text { Jumlah skor total validasi }}{\text { skor terting } i} \times 100 \%=\ldots \%
$$

Untuk menghitung angket respon siswa, menurut Riduwan (2015:15) rumus sebagai berikut.

$$
\operatorname{Pr}=\frac{A}{N} \times 100 \%
$$

Keterangan :

$\operatorname{Pr}=$ Persentase respon siswa

A = Proporsi siswa yang memilih Ya atau Tidak

$\mathrm{N}=$ Jumlah siswa yang mengisi angket 
3. Angket dinalisis secara kualitatif dengan berpedoman pada kriteria menurut Akbar (2015:78) sebagai berikut.

Tabel 2. Kriteria Kevalidan Media dan Materi

\begin{tabular}{|l|l|l|}
\hline Presentase & Kategori validitas & \multicolumn{1}{c|}{ Keterangan } \\
\hline $25 \%-40 \%$ & Tidak valid & Tidak boleh digunakan \\
\hline $41 \%-55 \%$ & Kurang valid & Tidak boleh digunakan \\
\hline $56 \%-70 \%$ & Cukup valid & Boleh digunakan setelah revisi besar \\
\hline $71 \%-85 \%$ & Valid & Boleh digunakan setelah revisi kecil \\
\hline $86 \%-100 \%$ & Sangat valid & Sangat baik digunakan \\
\hline
\end{tabular}

Tabel 3. Kriteria Kepraktisan Media yang Dikembangkan

\begin{tabular}{|l|l|l|}
\hline Presentase & Kategori validitas & \multicolumn{1}{|c|}{ Keterangan } \\
\hline $25 \%-40 \%$ & Tidak valid & Tidak boleh digunakan \\
\hline $41 \%-55 \%$ & Kurang valid & Tidak boleh digunakan \\
\hline $56 \%-70 \%$ & Cukup valid & Boleh digunakan setelah revisi besar \\
\hline $71 \%-85 \%$ & Valid & Boleh digunakan setelah revisi kecil \\
\hline $86 \%-100 \%$ & Sangat valid & Sangat baik digunakan \\
\hline
\end{tabular}

\section{B. Analisis Data Keefektifan}

1. Menghitung skor perolehan lembar evaluasi. Soal evaluasi diberikan kepada siswa kelas IV yang terdiri dari 20 soal pilihan ganda.

a) Menghitung hasil belajar setiap siswa (individu), dengan menggunakan rumus sebagai berikut.

Nilai hasil belajar siswa $=\frac{\text { jumlah skor pemerolehan }}{\text { jumlah skor } \text { maksimal }} \times 100$

b) Memenghitung presentase kelulusan siswa secara klsikal dengan menggunakan rumus sebagai berikut.

$$
P=\frac{L}{n} \times 100 \%
$$

Keterangan:

$\mathrm{P}=$ presentase kelulusan siswa secara klasikal

$\mathrm{L}=$ jumlah siswa yang lulus $\mathrm{KKM}$

$\mathrm{n}=$ jumlah seluruh siswa 


\section{HASIL PENELITIAN DAN PEMBAHASAN}

A. Uji Validasi Media Interaktif Subener

Tabel 4. Rekapitulasi Validasi Ahli Media dan Ahli Materi

\begin{tabular}{|c|c|c|c|}
\hline No. & Validasi & Presentase & Keterangan \\
\hline 1. & Ahli Media & $92 \%$ & Sangat baik untuk digunakan. \\
\hline 2. & Ali Materi & $90 \%$ & Sangat baik untuk digunakan. \\
\hline
\end{tabular}

Berdasarkan tabel diatas dapat disimpulkan bahwa hasil validasi ahli media diperoleh presentase $92 \%$ dan ahli materi memperoleh presentase $90 \%$. Dari hasil perolehan tersebut maka media subener dapatdinyatakan sangat baik untuk digunakan.

\section{B. Hasil Keefektifan Siswa}

Tabel 5. Data Hasil Nilai Evaluasi Uji Terbatas

\begin{tabular}{|c|c|c|c|}
\hline No. & Nama Siswa & Nilai & Keterangan \\
\hline 1. & Mohammad Zaky & 95 & Tuntas \\
\hline 2. & Nadya Saskia & 90 & Tuntas \\
\hline 3. & Nayara Aila & 85 & Tuntas \\
\hline 4. & Nikeisha Aqila & 85 & Tuntas \\
\hline 5. & Tasbika Nor Maulida & 85 & Tuntas \\
\hline 6. & Rafael Adam Yuniant & 90 & Tuntas \\
\hline 7. & Reyhan Favvell & 90 & Tuntas \\
\hline
\end{tabular}

Berdasarkan tabel diatas, pada uji terbatas dilakukan pada 7 siswa kelas IV. Pada uji terbatas terdapat 7 siswa yang mendapatkan nilai diatas KKM 75, sehingga diperoleh presentase kelulusan secara klasikal sebesar $100 \%$, sesuai pedoman keefektifan, media subener yang digunakan pada uji terbatas dinyatakan efektif dan kecakapan siswa pada pembelajaran materi sumber energi dikatakan sangat baik.

\section{Tabel 6. Data Nilai Hasil Evaluasi Uji Luas}

\begin{tabular}{|c|c|c|c|}
\hline No. & Nama Siswa & Nilai & Keterangan \\
\hline 1. & Hafidh Yusuf Abdillah & 90 & Tuntas \\
\hline 2. & Nindya Nesya & 95 & Tuntas \\
\hline 3. & Attika Latifa & 85 & Tuntas \\
\hline 4. & Aurora Eka & 90 & Tuntas \\
\hline 5. & Abidzar Valendtino & 95 & Tuntas \\
\hline
\end{tabular}




\begin{tabular}{|c|c|c|c|}
\hline 6. & Ahmad Annafi & 85 & Tuntas \\
\hline 7. & Ahmad Syakib & 95 & Tuntas \\
\hline 8. & Mohmad Kenzie & 85 & Tuntas \\
\hline 9. & Marvel Arahman & 85 & Tuntas \\
\hline 10. & Keyla Anandya & 90 & Tuntas \\
\hline 11. & Clarisa Aulia & 85 & Tuntas \\
\hline 12. & Dwika Melvin & 90 & Tuntas \\
\hline 13. & Aldo Oktaviano & 85 & Tuntas \\
\hline 14. & Mohammad Farhan & 90 & Tuntas \\
\hline 15. & Mohammad Yahya & 85 & Tuntas \\
\hline
\end{tabular}

Berdasarkan tabel diatas, setelah melakukan uji coba luas di SD Negeri Lirboyo 2 dengan menggunakan media pembelajaran subener, diperoleh hasil yaitu mediapembelajaran subener sudah efektif dan baik untuk digunakan dalam proses pemebelajaran materi sumber energi.

C. Hasil Angket Kepraktisan Guru dan Siswa

Tabel 7. Rekapitulisai Respon Guru dan Respon Siswa

\begin{tabular}{|c|c|c|ll|}
\hline No. & Perespon & Presentase & \multicolumn{1}{|c|}{ Keterangan } \\
\hline 1. & Respon guru & $90 \%$ & $\begin{array}{l}\text { Sangat praktis dan dapat } \\
\text { digunakan tanpa revisi. }\end{array}$ \\
\hline 2. & Respon siswa & $92 \%$ & $\begin{array}{l}\text { Sangat praktis dan dapat } \\
\text { digunakan tanpa revisi }\end{array}$ \\
\hline
\end{tabular}

Berdasarkan tabel diatas dapat disimpulkan bahwa hasil angket respon guru diperoleh presentase $90 \%$ dan hasil angket respon siswa memperoleh presentase $92 \%$. Dari hasil perolehan tersebut maka media subener dapat dinyatakan sangat praktis dan dapat digunakan tanpa revisi.

\section{KESIMPULAN}

Media pembelajaran subener dinyatakan sangat valid. Hal ini dibuktikan berdasarkan hasil validasi media memperoleh presentase skor $92 \%$ dan hasil validasi materi memperoleh presentase skor $90 \%$. Kriteria menunjukkan sangat valid dan sangat baik untuk digunakan, sehingga media subener materi sumber energi sangat valid dan sangat baik untuk digunakan oleh siswa kelas IV Sekolah Dasar.

Media pembelajaran subener dinyatakan efektif. Hal ini dibuktikan berdasarkan hasil sesudah pembelajaran yang dilakukan siswa dengan memenuhi kriteria kelulusan secara klasikal sebesar 100 \%. kriteria menunjukkan klasifikasi baik, maka siswa kelas IV SD Negeri 2 Lirboyodinyatakan sanggup menjelaskan materi sumber energi setelah menggunakan media pembelajaran subener.

Media pembelajaran subener dinyatakan praktis. Hal ini dibuktikan berdasarkan hasil angket dari guru dan siswa setelah pembelajaran. Kepraktisan media subener memenuhi kriteria dari respon guru diperoleh presentase skor sebesar $90 \%$ dan respon siswa presentase skor $92 \%$. Kriteria menunjukkan sangat praktis dan sangat baik untuk digunakan pada materi sumber energi di kelas IV Sekolah Dasar. 


\section{DAFTAR PUSTAKA}

Akbar, S . 2017. Instrumen Perangkat Pembelajaran. Bandung : PT. Remaja Rosdakarya

Arsyad, Azhar. 2007. Media Pembelajaran. Jakarta: Raja Grafindo Persada

Arsyad Azhari. 2014. Media Pembelajaran. Jakarta : Rajawali Pers

Arief S. Sadiman. dkk. (1996). Media Pendidikan: Pengertian, Pengembangan, dan. Pemanfaatannya. Jakarta: PT. Raya Grafindo Persada

BSNP. 2006. Standar Isi untuk Sekolah Menengah dan Dasar. Jakarta: Badan Standar Nasional Pendidikan

Daryanto. 2016. Media Pembelajaran. Yogyakarta: Gava Media

Munadi, Yudhi. 2008. Media Pembelajaran. Jakarta: Referensi. Jakarta: Prenada Media Group

Rusman. 2012. Model-Model Pembelajaran. Jakarta: Raja Grafindo

Ridwan. 2015. Skala Pengukuran Variabel-Variabel Penelitian. Bandung: Alfabeta

Rusman. 2017. Belajar dan Pembelajaran Berorientasi Standar Proses Pendidikan. Jakarta : Kencana

Sugiyono. 2019. Metode Penelitian Kuantitatif Kualitatif dan R\&D. Bandung: Alfabeta

Ismawati, Esti. 2012. Perencanaan Pengajaran Bahasa. Yogyakarta: Ombak.

Sadiman , Arief S, dkk . 2007. Media Pendidikan. Jakarta : Raja Grafindo Persada

Sugiono. 2010. Belajar \& Pembelajaran. Kediri: Univ Nusantara PGRI

Sugiyono. 2017. Metode Penelitian Kuantitatif, Kualitatif, Dan R\&D. Bandung: Alfabeta

UU No. 20 tahun 2003 , Sistem Pendidikan Nasional pasal 3. https://www.google.com/url?sa=t\&source=web\&rct=j\&url=http://luk.staff .ugm.ac.id. Diakses tanggal 15 Mei 2020

Munir. 2012. Multimedia Konsep \& Aplikasi dalam Pendidikan. Bandung : Alfabeta

Wati, Ega Rima. 2016. Ragam Media Pembelajaran. Yogyakarta:Kata Pena 